\title{
The necessity of disinfected toilet brushes - information policy of companies on disinfectants in private homes
}

\author{
Stefanie Wieck ${ }^{1,2}$
}

\begin{abstract}
Background: Nico Stehr, a German sociologist, presumes in his theory 'Moralisation of the market' that companies are willing to accept financial costs that result from moral considerations and put the interests of society over their own. It was examined whether this applies to companies that sell disinfectants to private users. It was assumed that in this case, companies would inform their customers extensively on the hazards posed by the use of disinfectants and would promote only those uses for which disinfectants are considered necessary.

Results: Fourteen websites for different product lines of disinfectants were analysed in 2012 whether they complied with legal requirements regarding advertisement and what use of disinfectants they proposed. Most of the companies followed these legal requirements regarding advertisements but promoted their products for more uses than necessary. Little changes were detected after a revisit of the websites in 2014. The websites of the companies did not give a full overview over the hazards and still promoted more uses than necessary.

Conclusions: The websites of the companies do not enable consumers to make information-based decisions regarding their use of disinfectants. To decrease risks whilst ensuring to keep the benefit of the use of disinfectants, it might be worth to consider more strict rules concerning appropriate uses of disinfectants in advertisements.
\end{abstract}

Keywords: Disinfectants; Biocides; Information policy; Content analysis

\section{Background}

Disinfectants are chemicals that are able to reduce the amount of germs on objects to be disinfected. They are regulated mainly in the EU Biocidal Products Regulation (BPR) 528/2012 [1]. They are used in several sectors by professional and non-professional users. The BPR separates disinfectants in five product types (Annex V): human hygiene, disinfectants and algaecides not intended for direct application to humans or animals, veterinary hygiene, food and feed area and drinking water [1]. In the professional sector, the use of disinfectants is very important to avoid infections, e.g. in hospitals or the food industry. The use of disinfectants in private homes by non-professional users however is intensely debated amongst scientists: In Germany, it is widely accepted

\footnotetext{
Correspondence: Stefanie.wieck@leuphana.de

${ }^{1}$ Institute for Sustainable and Environmental Chemistry, Leuphana University of Lüneburg, Scharnhorststr. 1, 21335 Lüneburg, Germany

${ }^{2}$ Centre of Quality Assurance in Study and Further Education, University of Rostock, Ulmenstraße 69, 18057 Rostock, Germany
}

that disinfectants should only be used by private persons if there are medical indications [2]. These might be infectious diseases of family members or if people in need of care are living in the household. The limitation of uses is due to the fact that disinfectants do not only inherit benefits but also might pose risks to humans and the environment [2]. Studies show that the use of disinfectants is only significantly reducing bacterial contamination in households if users follow a strict cleaning protocol $[3,4]$. In a setting where households were not informed how to use a disinfectant, the prevalence of bacterial contamination was not reduced [3]. A study on the effects of antibacterial products on infectious disease symptoms showed that using antibacterial products did not result in a reduction of the primarily viral infectious disease symptoms [5]. Reports of resistances are often accompanied by reports of wrong uses or insufficient cleaning [6]. This may also cause cross-resistances to antibiotics [7]. For example, it is under discussion whether a resistance to benzalkonium chloride, a disinfectant, 
might lead to a resistance to the antibiotic ciprofloxacin [8]. For many disinfecting substances, data on possible cross-resistances is not available; and for this reason, it is unclear which active substances pose the highest risks of these cross-resistances [7]. However, quaternary ammonium compounds, biguanides (i.e. surface active agents) and phenolics are considered as high-risk biocides concerning resistance problems [7]. For several substances (isothiazolones, anilides, diamidines, inorganic acids and their esters, alcohols), little information is available on resistance or tolerance [7]. Due to 'the nature of their interaction with the bacterial cell and their antimicrobial efficacy' [7], the Scientific Committee on Emerging and Newly Identified Health Risks (SCENIHR) considers them as medium-risk biocides. Several disinfectants have irritating or sensitising properties. A study showed that concentrations of the sensitising substances $\mathrm{CMI} / \mathrm{MI}$, glutardialdehyde, formaldehyde and chloroacetamide in disinfectants are in the same order of magnitude that leads to sensitising effects in laboratory tests [9]. Risks for the human health were especially high for spray applications or the use of concentrates for the cleaning of surfaces [9]. Some disinfectants or their metabolites can reach the environment. For example, the metabolite of triclosan, methyl-triclosan, was detected in surface waters [10] and biota [11]. Triclosan is also used in cosmetic products and in these cases does not fall under the BPR. Especially disinfection-by-products (DBP) which result from the reaction of halogenated oxidising substances with organic matter might pose risks that we are not aware of at the moment [12].

The advertisement for biocides and thus for disinfectants is regulated in Article 72 of the BPR [1]. It demands the statement 'Use biocides safely. Always read the label and product information before use.' on advertisements of biocidal products. Additionally, it prohibits misleading information in respect of risks from the product to human health, animal health or environment or its efficacy. It mentions examples not to be used like 'low-risk biocidal product', 'non-toxic', 'harmless', 'natural', 'environmentally friendly' or 'animal friendly'. The former Biocidal Products Directive 98/8/EC (BPD), which was in force during the first part of the evaluation in 2012, contained similar provisions in Article 22 [13].

The basis of the following considerations on the moral advertisement of disinfectants was a theory developed by the German sociologist Nico Stehr, who developed the theory of the 'Moralisation of the market' [14]. He assumed that companies take more responsibility for society and act morally. The environmental consciousness of society has been increasing over the last years [15] and leads to a rising demand for goods that are produced with moral background [14]. As a consequence, companies are willing to accept financial costs that result from moral considerations and put the interests of society over their own [14]. Critics say that companies do not act morally but only try to use moral for marketing purposes [16]. Following the theory of Stehr, it was assumed that companies would act morally and advertise disinfectants for private users only when they are medically needed.

The aim of this study was to evaluate whether German websites of companies promoting disinfectants to private users are communicating the principles of a responsible use correctly. This included information concerning hazards and what use of disinfectants they proposed. Additionally, it was analysed whether they complied with the regulations concerning the advertisement of biocides or whether they are promoting unnecessary uses like the disinfection of toilet brushes.

\section{Results and discussion}

\section{Compliance to legal requirements regarding advertisement}

In 2012, it was examined whether the companies were following the legal obligations of Article 22 of the BPD (now Article 72 of the BPR, Figure 1). The statement 'Use biocides safely. Always read the label and product information before use.' was missing on three websites. Also on three websites, misleading information regarding risks were found. These were:

- 'antivirus Flächendesinfektions-Spray': 'bei minimaler Belastung von Mensch, Material und Umwelt' (translation: 'with minimal impact on humans, materials and environment')

- 'HAKA Hygienespray': 'umweltfreundliche Kalkentfernung durch Aktivsauerstoff' (translation: 'eco-friendly removal of limescale with active oxygen')

- 'biff Anti-Schimmel': 'So halten Sie nicht nur Ihr Heim hygienisch sauber, sondern auch die Umwelt.' (translation: 'In this way you can not only keep your home clean but also the environment.')

Thirty-five percent of websites contained violations of Article 22. The confidence interval for the relative fraction is $0 \%$ to $43 \%$. It has to be noted that the statistical analysis is based only on 14 websites and hence not very powerful. However, this may indicate that there are more companies of the unknown basic population which do not fulfil legal requirements.

In 2014, these websites were evaluated again regarding the compliance to legal requirements for advertising laid down in the BPR. This time, all websites included the statement 'Use biocides safely. Always read the label and product information before use.' in some form. However, whilst the respective sentence with misleading information 


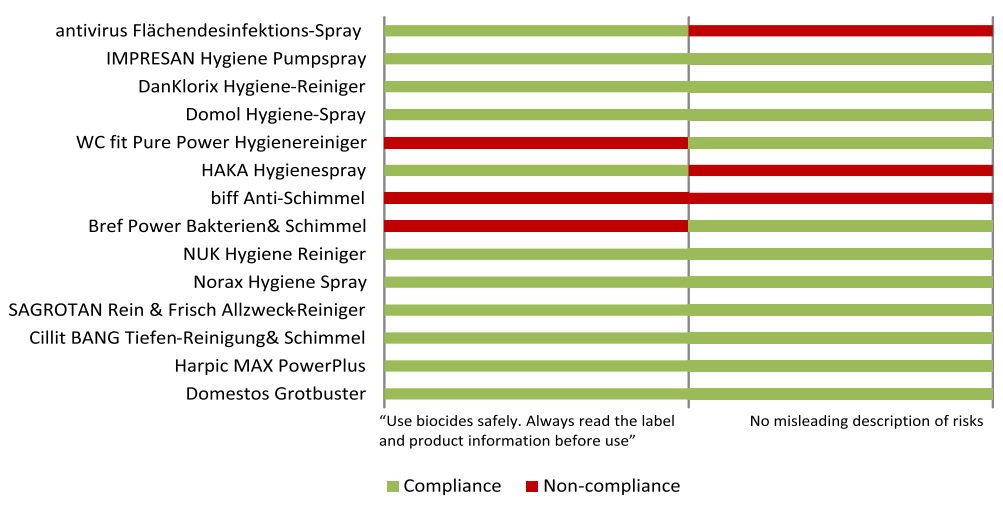

Figure 1 Compliance with Article 22 of the BPD regarding advertisement of biocides. This figure shows the (non-)compliance to Article 22 of the BPD. This Article demands the statement 'Use biocides safely. Always read the label and product information before use.' on advertisements of biocides. Additionally, it prohibits advertisements misleading in respect of the risks from the product to man or the environment. It mentions examples like 'low-risk biocidal product', 'non-toxic' or 'harmless'. The new BPR, which is in force since September 2013, contains similar provisions in Article 72 with the additional examples of 'natural', 'environmentally friendly' or 'animal friendly' for misleading indications.

regarding risks was removed on the website of 'biff AntiSchimmel, the other two above named examples can still be found in the websites. A screenshot of the two versions of the webpage of 'biff Anti-Schimmel' can be found in Additional file 1.

\section{Conditions of use}

It was analysed whether conditions of use of disinfectants were presented correctly by companies in 2012 and 2014 (Figure 2). This information was considered relevant for all 14 websites. In fact, the percentages remained almost the same over the 2 years. Only few websites of companies mention the need of disinfection if people in need of care are living in the household (one website) or if relatives are ill with infectious diseases (five websites). However, a lot of the companies' websites mention other reasons to use disinfectants in the household.
In 2012, these were $86 \%$ of the websites and in 2014 were $93 \%$. The rise in the categories 'Other reasons for the use of disinfectants' and 'Infectious diseases of relatives' is due to the new website http://www.impresan.de. This new website by Brauns-Heitmann GmbH \& Co. KG gives more information than did the old website of the company in 2012. An example for extensive reasons mentioned for the use of a disinfectant are the recommendations for disinfection with 'DanKlorix Hygiene-Reiniger' under http:// www.danklorix.de/tipps_desinfektion.php. Here, it recommends disinfection of: drains and sinks, floor cloths and mops, baby bottles, breadboxes, bathrooms, shower cubicles, shower rooms, clinical thermometers, feeding dishes of pets, rubber mats for showers and bathtubs, urine and faeces of dogs on fences and posts, cat litter pans, potties, combs, nail brushes, hair rollers, dustbins, chopping boards (plastic and wood), toys, pet cages, toilet brushes,

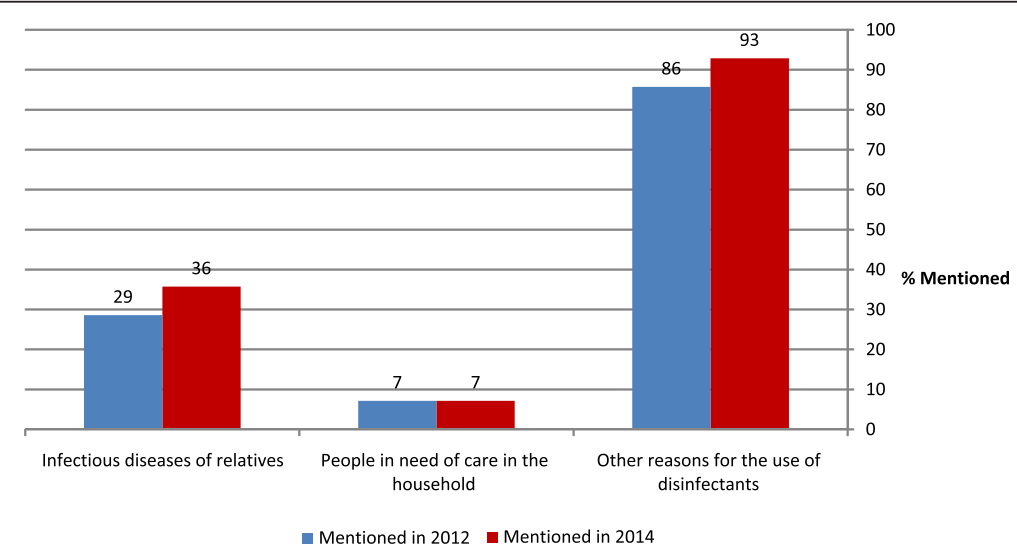

Figure 2 Conditions of use proposed on the websites. This figure shows the reasons that are presented on the websites when disinfectants should be used. In Germany, it is widely accepted that disinfectants should only be used by private users if it is medically indicated. All other reasons proposed on websites were coded in the category 'Other reasons for the use of disinfectants'. It compares the differences of the recommendations between 2012 and 2014. 
door handles, water containers and canisters, toothbrushes and toothbrush mugs (screenshots in Additional file 1). The revisit of the website in December 2014 showed that this list had not changed in that time except for the addition of dishcloths and dishwashing brushes.

On the other hand, there are also websites that give only rough advice on conditions of use of disinfectants. An example is http://www.haka.de/de/hygienesprayflasche.html where it only recommends the use of the product for the 'quick and targeted cleaning of small areas'. This could lead to an unconsidered use of disinfectants by users because they are not aware of the specific cases when disinfectants should be used. There was only one website that recommended that this disinfectant should only be used if the risk of pathogenic germs was high. This was the webpage http://www.fit.de/fit/fitratgeber/ratgeber-reinigen/ of fit $\mathrm{GmbH}$ (see Additional file 1). However, it would be even more helpful for the consumers if this information would be given on the website of the respective product 'WC fit Pure Power Hygienereiniger' and not only on the advisory section of the website. Thirteen out of fourteen websites fail in restricting sufficiently their recommendations regarding the conditions of use to the consumers. This might lead to an overuse of disinfectants under conditions where their use might not be indicated.

\section{Information on hazardous properties}

All websites were examined in 2014 whether identified hazardous properties of the respective disinfectants were mentioned in the texts. Product-specific hazardous properties (irritant, corrosive or sensitising properties, crossresistance to antibiotics, hazardous to the environment and the formation of DBP) were only analysed if the product posed such hazard (Table 1). The decision whether a product had irritant, corrosive or sensitising properties or posed a hazard to the environment was based on the respective material safety data sheets (MSDSs). For 'NUK Hygiene Reiniger', information was gathered from the product label, because no MSDS was available. For 'Norax Hygiene Spray', no MSDS was available and no products were found in local supermarkets. This product was therefore excluded from this part of the analysis. Irritant, corrosive and sensitising properties were based on classification of the respective product, environmental hazards on classification or on water hazard classes. Water hazard classes are based on the German General Administrative Regulation under the Federal Water Act on the Classification of Substances Hazardous to Water in Water Hazard Classes. A water hazard class between 1 (slightly polluting substance) and 3 (severely hazardous to water) was mentioned for each product in the respective MSDS, except for 'Cillit BANG Tiefen-Reinigung \& Schimmel' and 'Harpic MAX Power
Plus', where no class was mentioned. For 'NUK Hygiene Reiniger', also no water hazard class was available as this type of information cannot be found on the product label. Resistance and cross-resistance to antibiotics was relevant for products containing quaternary ammonium compounds because these are considered as high-risk biocides concerning resistance problems. The formation of DBP was considered relevant for products containing sodium hypochlorite. As none of these products was classified as sensitising, this property is not listed in Table 1. Additionally, it was examined whether the websites reported hazards due to bacteria to highlight information regarding benefits by the use of disinfectants.

The span of information given on the companies' websites ranged from information in up to two categories to none information regarding hazards (Figure 3). The hazardous property mentioned most frequently is skin irritation (relevant for eight websites, mentioned by six). For websites including an online shop, this might be due to the Regulation (EC) No. 1272/2008 on classification, labelling and packaging of substances and mixtures. It requests in Article 48 (2) that an 'advertisement for a mixture classified as hazardous which allows a member of the general public to conclude a contract for purchase without first having sight of the label shall mention the type or types of hazard indicated on the label' [17]. None of these websites mentioned environmental hazards due to the use of disinfectants or DBP. In some cases, they even denied hazards posed by their products. For example, at the webpage http://www.antiseptica-home.de/ fragen/antworten-zur-haendedesinfektion-und-flaechendesinfektion, the answer to the question 'Can germs develop resistances against disinfectants?' is: 'Developments of resistance of germs towards disinfectants are not known. Also, disinfectants do not lead to resistances against antibiotics. [...]' (translation, screenshot in Additional file 1). This is contrary to the conclusions of the SCENIHR [7]. Three out of thirteen websites of companies do not give any information regarding hazards of disinfectants whilst giving information regarding risks posed by bacteria. This shows that there is no general lack of information on these websites, but a selective choice of information towards the benefits of disinfectants.

\section{Conclusions}

The results show that none of the evaluated companies communicated all relevant information regarding hazards of the product and promoted only necessary uses at the same time. Whilst some websites gave more differentiated information than others (see the example of fit $\mathrm{GmbH}$ above), a website contained wrong information (see example under 'Information on hazardous properties'); and in 2012, three of them gave misleading information regarding risks. The information that was 
Table 1 Websites and sample products and respective hazardous properties

\begin{tabular}{|c|c|c|c|c|c|c|c|c|}
\hline Company name & Domain & Sample product & Active substance & Irritating & Corrosive & $\begin{array}{l}\text { Resistance/ } \\
\text { cross-resistance } \\
\text { to antibiotics }\end{array}$ & $\begin{array}{l}\text { Hazard to the } \\
\text { environment }\end{array}$ & DBPs \\
\hline \multirow[t]{2}{*}{$\begin{array}{l}\text { Antiseptica } \\
\text { chem. pharm. } \\
\text { Produkte GmbH }\end{array}$} & \multirow[t]{2}{*}{ www.antiseptica-home.de } & \multirow[t]{2}{*}{$\begin{array}{l}\text { Antivirus Flächendesinfektions-Spray } \\
\text { (spray for surface disinfection) }\end{array}$} & $\begin{array}{l}\text { Poly(hexamethylenebicyanoguanide- } \\
\text { hexamethylenediamine) hydrochloride } \\
\text { (PHMB, CAS-No. 27083-27-8) }\end{array}$ & & & $x$ & $x$ & \\
\hline & & & $\begin{array}{l}\text { Didecyl dimethyl ammonium chloride } \\
\text { (DDAC, CAS-No. 7173-51-5) }\end{array}$ & & & & & \\
\hline \multirow{2}{*}{$\begin{array}{l}\text { Brauns-Heitmann } \\
\text { GmbH \& Co. KG }\end{array}$} & \multirow{2}{*}{$\begin{array}{l}\text { www.brauns-heitmann- } \\
\text { shop.de }\end{array}$} & \multirow{2}{*}{$\begin{array}{l}\text { IMPRESAN Hygiene Pumpspray (spray for } \\
\text { surface disinfection) }\end{array}$} & Ethanol (64-17-5) & & & & $x$ & \\
\hline & & & Propan-2-ol (CAS-No. 67-63-0) & & & & & \\
\hline $\begin{array}{l}\text { Colgate- } \\
\text { Palmolive GmbH }\end{array}$ & www.danklorix.de & $\begin{array}{l}\text { DanKlorix Hygiene-Reiniger (liquid } \\
\text { cleaning agent and bleach) }\end{array}$ & Sodium hypochlorite (CAS-No. 7681-52-9) & $x$ & & & $x$ & $x$ \\
\hline \multirow{3}{*}{$\begin{array}{l}\text { Dirk Rossmann } \\
\text { GmbH }\end{array}$} & \multirow[t]{3}{*}{ www.rossmann.de } & \multirow{3}{*}{$\begin{array}{l}\text { Domol Hygiene-Spray (spray for surface } \\
\text { disinfection) }\end{array}$} & Ethanol (CAS-No.64-17-5) & $x$ & & & $x$ & \\
\hline & & & Propan-1-ol (CAS-No. 71-23-8) & & & & & \\
\hline & & & Propan-2-ol (CAS-No. 67-63-0) & & & & & \\
\hline fit $\mathrm{GmbH}$ & www.fit.de & $\begin{array}{l}\text { WC fit Pure Power Hygienereiniger } \\
\text { (disinfecting toilet cleaner) }\end{array}$ & Formic acid (CAS-No. 64-18-6) & $x$ & & & $x$ & \\
\hline $\begin{array}{l}\text { HAKA Kunz } \\
\text { GmbH }\end{array}$ & www.haka.de & $\begin{array}{l}\text { HAKA Hygienespray (spray for surface } \\
\text { disinfection) }\end{array}$ & Hydrogen peroxide (CAS-No. 7722-84-1) & $x$ & & & $x$ & \\
\hline $\begin{array}{l}\text { Henkel AG \& Co. } \\
\text { KGaA }\end{array}$ & www.henkel-reiniger.de & $\begin{array}{l}\text { biff Anti-Schimmel (spray for surface } \\
\text { disinfection and removal of mould) }\end{array}$ & Sodium hypochlorite (CAS-No. 7681-52-9) & $x$ & & & $x$ & $x$ \\
\hline $\begin{array}{l}\text { Henkel AG \& Co. } \\
\text { KGaA }\end{array}$ & www.bref-power.de & $\begin{array}{l}\text { Bref Power Bakterien \& Schimmel (spray } \\
\text { for surface disinfection and removal of } \\
\text { mould) }\end{array}$ & Sodium hypochlorite (CAS-No. 7681-52-9) & $x$ & & & $x$ & $x$ \\
\hline \multirow[t]{2}{*}{ MAPA GmbH } & \multirow[t]{2}{*}{ www.nuk-shop.de } & \multirow{2}{*}{$\begin{array}{l}\text { NUK Hygiene Reiniger (spray for surface } \\
\text { disinfection) }\end{array}$} & L(+)-Lactic acid (CAS-No. 79-33-4) & & & & $?$ & \\
\hline & & & Formic acid (CAS-No. 64-18-6) & & & & & \\
\hline Norax GmbH & www.norax.de & $\begin{array}{l}\text { Norax Hygiene Spray (spray for surface } \\
\text { disinfection) }\end{array}$ & $\begin{array}{l}\text { Benzalkonium chloride (BAC, CAS-No. } \\
68424-85-1 \text { ) }\end{array}$ & \multicolumn{2}{|c|}{$\begin{array}{l}\text { Excluded because } \\
\text { of missing data }\end{array}$} & & & \\
\hline $\begin{array}{l}\text { Reckitt Benckiser } \\
\text { Group plc }\end{array}$ & www.sagrotan.de & $\begin{array}{l}\text { SAGROTAN Rein \& Frisch Allzweck- } \\
\text { Reiniger (spray for surface disinfection) }\end{array}$ & $\begin{array}{l}\text { Benzalkonium chloride (BAC, CAS-No. } \\
68424-85-1 \text { ) }\end{array}$ & & & $x$ & $x$ & \\
\hline $\begin{array}{l}\text { Reckitt Benckiser } \\
\text { Group plc }\end{array}$ & www.cillitbang.de & $\begin{array}{l}\text { Cillit BANG Tiefen-Reinigung \& } \\
\text { Schimmel (spray for surface disinfection } \\
\text { and removal of mould) }\end{array}$ & Sodium hypochlorite (CAS-No. 7681-52-9) & $x$ & & & $?$ & $x$ \\
\hline $\begin{array}{l}\text { Reckitt Benckiser } \\
\text { Group plc }\end{array}$ & www.harpic.de & $\begin{array}{l}\text { Harpic MAX PowerPlus (disinfecting toilet } \\
\text { cleaner) }\end{array}$ & Hydrochloric acid (CAS-No. 7647-01-0) & & $x$ & & $?$ & \\
\hline $\begin{array}{l}\text { Unilever } \\
\text { Deutschland } \\
\text { GmbH }\end{array}$ & www.domestos.de & $\begin{array}{l}\text { Domestos Grot Buster (gel for surface } \\
\text { disinfection) }\end{array}$ & Sodium hypochlorite (CAS-No. 7681-52-9) & $x$ & & & $x$ & $x$ \\
\hline
\end{tabular}




\begin{tabular}{|c|c|c|c|c|c|c|}
\hline & \begin{tabular}{|c|} 
Resistance \\
against \\
disinfectants and \\
antibiotics
\end{tabular} & $\begin{array}{l}\text { Irritating } \\
\text { properties }\end{array}$ & $\begin{array}{l}\text { Corrosive } \\
\text { properties }\end{array}$ & $\begin{array}{l}\text { Effects on the } \\
\text { environment }\end{array}$ & $\begin{array}{c}\text { Effects of disinfection } \\
\text { by-products }\end{array}$ & $\begin{array}{l}\text { Risks posed } \\
\text { by bacteria }\end{array}$ \\
\hline $\begin{array}{l}\text { antivirus Flächen- } \\
\text { desinfektions-Spray }\end{array}$ & & & & & & \\
\hline $\begin{array}{l}\text { IMPRESAN Hygiene } \\
\text { Pumpspray }\end{array}$ & & & & & & \\
\hline $\begin{array}{l}\text { DanKlorix Hygiene- } \\
\text { Reiniger }\end{array}$ & & & & & & \\
\hline Domol Hygiene-Spray & & & & & & \\
\hline $\begin{array}{l}\text { WC fit Pure Power } \\
\text { Hygienereiniger }\end{array}$ & & & & & & \\
\hline HAKA Hygienespray & & & & & & \\
\hline biff Anti-Schimmel & & & & & & \\
\hline $\begin{array}{l}\text { Bref Power } \\
\text { Bakterien\&Schimmel }\end{array}$ & & & & & & \\
\hline NUK Hygiene Reiniger & & & & & & \\
\hline Norax Hygiene Spray & & & & & & \\
\hline $\begin{array}{l}\text { SAGROTAN Rein \& Frisc } \\
\text { Allzweck-Reiniger }\end{array}$ & & & & & & \\
\hline $\begin{array}{l}\text { Cillit BANG Tiefen- } \\
\text { Reinigung\&Schimmel }\end{array}$ & & & & & & \\
\hline Harpic MAX PowerPlus & & & & & & \\
\hline Domestos Grotbuster & & & & & & \\
\hline
\end{tabular}

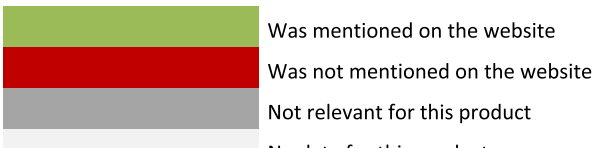

Figure 3 Information regarding hazards posed by the products. This figure shows which hazards were considered relevant for the respective products and whether the websites mentioned these hazards.

presented showed a selective choice of information in three cases. These cases gave information regarding risks posed by bacteria whilst at the same time they did not give any information regarding the hazards posed by their product. Unnecessary uses were promoted on 13 websites. The results indicate that the companies do not act morally as presumed by Stehr but try to maximise the sales of their product.

For future offers of information, it would be important to know which sources the consumers are using and whether they reflect on the use of disinfectants at all. In Germany, over $70 \%$ of the consumers are reading instructions on the back of the package to find information about cleaning products, and more than $30 \%$ are looking for product information on the internet [18]. The respondents generally consulting the internet on information on chemical products used mainly the manufacturers' sites (31\%) with consumer protection associations and Google as second most mentioned source (both 21\%) [18]. Thus, offers of information by other stakeholders are an important source of information, but these were not evaluated. The limitation of the evaluation to websites excludes offline offers of information that might be given by the companies e.g. on labels or packaging of their products. Also, other advertisement channels like print, radio or video were not included. These might be more important information channels for those user groups that are not using the internet regularly. However, it is not likely that the information given by a company differs with regard to the fundamental content between the information channels, though the extent of information is supposed to be different. Therefore, the main conclusions drawn from the evaluation of the websites are supposed to be true for other information channels as well. Future research has to verify this.

Only the written information given on websites was evaluated and discussed. As a consequence, information that was given in videos, pictures and animations was not included. These might be particularly important for the understanding of information by the consumers. However, the focus of the evaluation was whether information was given at all and not on how consumers would understand this information. In general, it can be assumed that the information, which was searched for on the websites, would be given in writing. However, information might exist which was not included in these analyses because of its form. 
Results indicate that most companies are following legal requirements. It should be considered if more detailed legal requirements for the companies might help to give consumers broader information regarding the hazards of the products they are using. At the same time, surveillance of websites should be increased to ensure that consumers are informed correctly. The prohibition of unnecessary uses in advertisements of disinfectants or all biocides would presumably help to limit their use to cases where necessary. Thus, hazards could be avoided whilst ensuring to keep the benefit of disinfectants.

\section{Methods}

Basis of this study was the information provided by companies on their websites in regard of the use of disinfectants. The method used was a conceptual content analysis which was adapted for online content. Content analysis is an empirical method to describe systematically and intersubjectively reproducible messages in form and content. It aims at an interpretative inference to external circumstances [19]. The characteristics of an online content analysis are according to Welker et al. [20]:

- Volatility and dynamics of the contents which require archiving

- High degree of multimedia capability and the associated coactions of different media

- Non-linearity complicates the distinction of the recording unit

- Unknown basic population requires a sampling strategy of the websites

\section{Sample}

Websites for product lines including disinfectants were analysed. As the basic population of these websites concerning disinfectants for non-professionals is unknown, a sampling strategy was applied for the first analyses. This was not random; as for a random strategy, the basic population would have to be known. The missing knowledge regarding the basic population leads to an uncertainty as it is not clear whether the sample is representative.

The browser used in 2012 was Mozilla Firefox 12.0, and private mode was used to exclude personalised search results. In 2014, Mozilla Firefox 34.0.5 was used in private mode. The websites were identified by searching the five most used search engines in Germany: Google, Yahoo, Bing, T-Online and Ask [21] with several search operations using different keywords. Keywords used for search operations were 'Desinfektionsmittel', 'Hygiene + Reiniger' (and-connection) and specific product names. The selection of product names was based on the assortment of the most popular drugstores in Germany that have online shops: Rossmann (www.rossmannversand.de) and
Schlecker (www.schlecker.de) [22]. The first 30 products of their respective assortment were checked whether a website was existing that presented information regarding the product line. If this was the case, the website was included. Websites that only compared prices or were just selling the products were not included. The sampling strategy resulted in 14 websites of different product lines to be analysed (Table 1). These were slightly different in 2012 and 2014 due to structural changes in those websites. For example, 'IMPRESAN Hygiene Pumpspray' can be found in 2014 on a specific website for the IMPRESAN-product line. This was not the case in 2012.

\section{Definition of the recording unit}

Due to the non-linearity of websites, the definition of the recording unit is an important parameter during the selection of samples. Within one domain, only those pages were analysed that were linked with hyperlinks and dealt with disinfectants, their use or their avoidance (Additional file 2). To find these pages, also internal search operations were used. One search was conducted with the keyword 'Desinfektionsmittel' and another one with 'Hygiene'. If the website of a product line had several pages for different products, only one sample product page was chosen in 2012 and analysed. It was assumed that within one website, the amount of product-specific information would be the same for all products. As some companies have different websites for different product lines, up to three products from one company were analysed. However, the amount of information was supposed to be different between websites for different product lines. If possible, webpages on disinfectant sprays for surfaces were chosen to increase the comparability between the products. Only texts were analysed; pictures, videos or animations were disregarded.

For the second analyses in 2014, those same products were revisited which had been chosen in the first round. No further sampling of other products was conducted. If the respective links had changed during that time, the sample product was searched on the new website. This was the case for 'NUK Hygiene Reiniger'. Hyperlinks dealing with disinfectants, their use or their avoidance were searched and analysed in the same manner as during the analyses in 2012.

\section{Archiving}

To make this study reproducible, the analysed websites were archived with the programme Tenmax Teleport Pro [23]. Those websites, which could not be archived by the programme, e.g. because of flash programming, were archived with screenshots during the second batch of analyses in 2014. This was not done in 2012. 


\section{Coding and analysis}

A code system was developed using empirical forming of categories which based on the theoretical background on disinfectants and their use. Categories were further specified by analysing text samples. Main categories that were analysed were 'hazards', 'proposed use of disinfectants' and 'compliance to legal requirements regarding advertisement'. Specific subcategories were defined under these main categories. For the main category 'hazards', these subcategories were the possible hazardous properties of the products ('resistance against disinfectants and antibiotics', 'irritating properties', 'corrosive properties', 'effects on the environment' and 'effects of disinfection byproducts') and 'risks posed by bacteria'. For the main category, 'proposed use of disinfectants' subcategories were 'people in need of care in the household', 'infectious diseases of relatives' and 'other reasons for the use of disinfectants'. For the third main category, 'compliance to legal requirements regarding advertisement' subcategories were 'Use biocides safely. Always read the label and product information before use.' and 'no misleading description of the risks'.

To evaluate whether users of the website were given specific information, it was differentiated whether the information was mentioned or not (conceptual analysis). To operationalise the subcategories, indicators were defined for each subcategory describing examples for the content to be coded. An example for an indicator is the indicator 'Bakterien, Viren oder andere Mikroorganismen können krank machen' ('Bacteria, viruses or other microorganisms can make someone ill') of the subcategory 'risks posed by bacteria'. Sentences were defined as coding units as the categories were depending on meanings and not on single words. The first analyses regarding the conditions of use and compliance to legal requirements were conducted during the period of 21.05 .12 to 10.06 .12 by the author. The second analyses, also including the presentation of the hazardous properties, were conducted from 13.12.14 to 21.12.14 by the author as well. Thus, no intercoder reliability was established.

\section{Additional files}

Additional file 1: Contains screenshots of websites that are discussed in the article.

Additional file 2: Contains addresses of webpages that were analysed in 2012 and 2014.

\section{Abbreviations}

BPD: Biocidal Products Directive 98/8/EC; BPR: Biocidal Products Regulation (EU) 528/2012; DBP: disinfection by-product; MSDS: material safety data sheet; SCENIHR: Scientific Committee on Emerging and Newly Identified Health Risks.

\section{Competing interests}

The author declares that she has no competing interests.
Authors' contributions

SW carried out all work related to the study and wrote the article.

\section{Authors' information}

SW is currently a PhD-student at the Institute for Sustainable and Environmental Chemistry at the Leuphana University of Lüneburg and is working at the German Federal Environment Agency (Umweltbundesamt). She conducted this study as a master thesis to receive the graduation as 'Master of Arts' at the University of Rostock, Germany. This paper does not necessarily reflect the opinion or the policies of the German Federal Environment Agency.

\section{Acknowledgements}

The author would like to acknowledge Heiko Grunenberg, Leuphana University of Lüneburg, and Dr. Eckhard Festerling, University of Rostock, who were the supervisors of the master thesis and supported the design of the study with their advice.

Received: 7 August 2014 Accepted: 9 January 2015

Published online: 23 January 2015

\section{References}

1. Regulation (EU) No 528/2012 of the European Parliament and of the Council of 22 May 2012 Concerning the Making Available on the Market and Use of Biocidal Products. 2013.

2. Pieper C, Schwebke I, Noeh I, Uhlenbrock K, Hübner N-O, Solecki R. Antimikrobielle Produkte im Haushalt - eine Betrachtung zu Auswirkungen auf Gesundheit und Umwelt sowie zum Nutzen für den Anwender. Hyg Med. 2014;39:9.

3. Josephson K, Rubino J, Pepper I. Characterization and quantification of bacterial pathogens and indicator organisms in household kitchens with and without the use of a disinfectant cleaner. J Appl Microbiol. 1997;83:737-50.

4. Medrano-Félix A, Martínez C, Castro-del Campo N, León-Félix J, Peraza-Garay $F$, Gerba CP, et al. Impact of prescribed cleaning and disinfectant use on microbial contamination in the home. J Appl Microbiol. 2011;110:463-71.

5. Larson E, Lin S, Gomez-Pichardo C, Della-Latta P. Effect of antibacterial home cleaning and handwashing products on infectious disease symptoms: a randomized, double-blind trial. Ann Intern Med. 2004;140:321-9.

6. McDonnell G, Russell D. Antiseptics and disinfectants: activity, action and resistance. Clin Microbiol Rev. 1999;12:147-79.

7. SCENIHR. Assessment of the antibiotic resistance effects of biocides. Brüssel: European Commission; 2009.

8. McCay P, Ocampo-Sosa A, Fleming G. Effect of subinhibitory concentrations of benzalkonium chloride on the competitiveness of Pseudomonas aeruginosa grown in continuous culture. Microbiology. 2010;156:30-8.

9. Hahn S, Schneider K, Gartiser S, Heger W, Mangelsdorf I. Consumer exposure to biocides - identification of relevant sources and evaluation of possible health effects. Environ Health. 2010;9:7.

10. Von der Ohe P, Schmitt-Jansen M, Slobodnik J, Brack W. Triclosan- a forgotten priority substance? Environ Sci Pollut Res. 2011;19:585-91.

11. Böhmer W, Rüdel H, Wenzel A, Schröter-Kermani C. Retrospective monitoring of triclosan and methyl-triclosan in fish: results from the German Environmental Specimen Bank. ORGANOHALOGEN Compd. 2004;66:1516-21.

12. Richardson S, Plewa M, Wagner E, Schoeny R, Demarini D. Occurrence, genotoxicity, and carcinogenicity of regulated and emerging disinfection by-products in drinking water: a review and roadmap for research. Mutat Res. 2007;636:178-242.

13. Directive $98 / 8 /$ EC of the European Parliament and of the Council of 16 February 1998 Concerning the Placing of Biocidal Products on the Market. 1998.

14. Stehr N. Die Moralisierung der Märkte: eine Gesellschaftstheorie. Frankfurt am Main: Suhrkamp; 2007.

15. Borgstedt S, Christ T, Reusswig F. Umweltbewusstsein in Deutschland 2010 Heidelberg: Umweltbundesamt; 2010 [UBA, BMU (Series editors)].

16. Ungericht B, Raith D, Korenjak T. Corporate Social Responsibility Oder Gesellschaftliche Unternehmensverantwortung?: kritische Reflexionen, empirische Befunde und politische Empfehlungen. Wien: Lit; 2008.

17. Regulation (EC) No 1272/2008 of Th European Parliament and of the Council of 16 December 2008 on Classification, Labelling and Packaging of Substances and Mixtures, Amending and Repealing Directives 67/548/EEC and 1999/45/EC, and Amending Regulation (EC) No 1907/2006. 2009. 
18. Epp A, Hertel RF, Böl G-F. Chemicals in daily life - a representative survey among German consumers on products containing chemicals. Berlin: Bundesinstitut für Risikobewertung; 2009.

19. Früh W. Inhaltsanalyse Theorie Und Praxis. 7. überarbeitete Auflage. Konstanz: UVK-Verlagsgesellschaft; 2011

20. Welker M, Wünsch C, Böcking S, Bock A, Friedemann A, Herbers M, et al. Die Online-Inhaltsanalyse: methodische Herausforderung, aber ohne Alternative. In: Die Online-Inhaltsanalyse: Forschungsobjekt Internet. Edited by Welker M Wünsch C. Köln: Von Halem Verlag; 2010. [Deutsche Gesellschaft für OnlineForschung (Series editor): Neue Schriften zur Online-Forschung, vol. 8]

21. Marktanteile von Suchmaschinen in Deutschland im April 2011 http://de. statista.com/statistik/daten/studie/167841/umfrage/marktanteileausgewaehlter-suchmaschinen-in-deutschland/.

22. Umsatz der führenden Drogeriemärkte in Deutschland im Jahr 2008 (in Milliarden Euro) http://de.statista.com/statistik/daten/studie/5482/umfrage/ top-5-der-drogeriemaerkte-in-deutschland-nach-umsatz-im-jahr-2008/.

23. Teleport Pro, http//www.tenmax.com/teleport/pro/home.htm.

Submit your manuscript to a SpringerOpen ${ }^{\circ}$ journal and benefit from:

- Convenient online submission

- Rigorous peer review

- Immediate publication on acceptance

- Open access: articles freely available online

- High visibility within the field

- Retaining the copyright to your article

Submit your next manuscript at $>$ springeropen.com 